\title{
Evaluation of jute leaf as substitute of fish meal in the diet of mrigal (Cirrhinus cirrhosus) fingerlings
}

\author{
K.M.S. Rana, P. Biswas and M.A. Salam* \\ Received 29 April 2020, Revised 28 May 2020, Accepted 20 June 2020, Published online 30 June 2020
}

\begin{abstract}
A B S T R A C T
The study was conducted to identify jute leaf powder as an alternate to fish meal in diets of juvenile mrigal (Cirrhinus cirrhosus) for 60 days. Tossa jute (Corchorus olitorius) leaf was selected to utilize this unexplored nutritious resource rather leaving under water for potential pollution. Three isonitrogenous test diets were prepared and applied as treatments $(\mathrm{T})$ in triplicates $(\mathrm{R})$. In control $\left(\mathrm{T}_{\mathrm{o}}\right)$ dietary inclusion rate of fish meal was $30 \%$, of which $10 \%$ was substituted with jute leaf powder in $\mathrm{T}_{10}$ and in $\mathrm{T}_{20}$ replacement was $20 \%$. Mrigal fingerlings $(9.38 \pm 0.13 \mathrm{~cm}$ and $7.94 \pm 0.26 \mathrm{~g})$ were stocked in nine plastic half drums $(0.26$ $\mathrm{m}^{2}$ each) at 10 fish per drum and fed test diets. Although, growth parameters among the treatments were statistically similar, the highest mean length gain, weight gain, SGR and production were $1.51( \pm 0.18) \mathrm{cm}, 2.96( \pm 0.13) \mathrm{g}, 0.53( \pm 0.03) \% /$ day and $4084.00( \pm 50.67)$ $\mathrm{kg} \mathrm{ha}^{-1}$, respectively in $\mathrm{T}_{10}$. However, significantly higher $(\mathrm{P}<0.05)$ survival was found in $\mathrm{T}_{10}$ (93.33\%) and $\mathrm{T}_{20}(90.00 \%)$ compared to $\mathrm{T}_{\mathrm{o}}(83.33 \%)$. Juveniles in $\mathrm{T}_{10}$ and $\mathrm{T}_{20}$ showed better tolerance to low $\mathrm{pH}$ stress than $\mathrm{T}_{0}$. Water quality parameters were within acceptable range in all the treatments. Moreover, carcass composition of fish was statistically similar among the treatments. Importantly, feed formulation cost was reduced by $3.7 \%$ and $20.4 \%$ in $\mathrm{T}_{10}$ and $T_{20}$, respectively compared to $T_{0}$. Therefore, the results signify that jute leaf powder could be a promising substitute of fishmeal in mrigal diet without hampering growth along with improved survival and low feed cost.
\end{abstract}

Keywords: Fish meal, Isonitrogenous, Jute leaf, Mrigal.

Department of Aquaculture, Bangladesh Agricultural University, Mymensingh-2202, Bangladesh.

*Corresponding author’s email: masalambau@gmail.com (M.A. Salam)

Cite this article as: Rana, K.M.S., Biswas, P. and Salam, M.A. 2020. Evaluation of jute leaf as substitute of fish meal in the diet of Mrigal (Cirrhinus cirrhosus) fingerlings. Int. J. Agril. Res. Innov. Tech. 10(1): 117-122. https://doi.org/10.3329/ijarit.v10i1.48103

\section{Introduction}

Aquaculture is one of the promising and fastest food producing sectors in Bangladesh, which has brought the country to the top $5^{\text {th }}$ position in global context (FAO, 2018). In order to keep pace with the increasing demand, this sector has been intensified greatly. Therefore, the demand for fishmeal, the prime source of dietary protein in aqua-feed (Katheline et al., 2019; Hardy, 1999), is increasing dramatically to support the intensification. It has been estimated that aquaculture feed industry used 372.4 million tons of fish meal and 83.5 million tons of fish oil in 2006, which was equivalent to 16.6 million tons of small pelagic forage fishes (Tacon and Metian, 2008; FAO, 2012). Hence, fish meal based feeding practices in aquaculture is a threat to the conservation of wild fish population, which has already been under reckless fishing pressure. Besides high price, adulteration and uncertain availability of fish meal adversely affect profitability of fish farming (Alceste, 2000). Therefore, the quest for possible cost effective alternate protein sources to replace (complete or partial) fish meal in the aqua-feed has become paramount (Magouz et al., 2008). As animal protein sources are mostly expensive and scarce, locally available plant sources are considered to be one of the cheaper alternatives to lessen feed cost without compromising the quality (Munguti et al., 2006; Francis et al., 2012). Addressing the issue, the present venture has been designed with jute (Corchorus olitorius) leaf powder to attain a more economically sustainable fish production by utilizing non-conventional protein sources as a substitution of fishmeal in the diet.

C. olitorius, commonly known as tossa/ traditional jute (also known as long-fruited jute, jute mallow and jew's mallow), is an erect, annual herb belonging to flowering plant of the family 
Tiliaceae (Singh et al., 2016). It is one of the abundantly cultured jute verities in Bangladesh and West Bengal (India). In Bangladesh, a large area of around 8.0 - 8.2 lakh hectares has been under jute and kenaf cultivation ( $85 \%$ tossa jute, $8 \%$ white jute and $7 \%$ kenaf of the area) with annual production of 85-90 lakh bales (Saha, 2011; Al-Mamun et al., 2017). The leaves of jute, which are demulcent, diuretic, febrifuge and also serve as tonic (Singh et al., 2016), are very popular as a leafy vegetable in many Asian, African and European countries (Furumuto et al., 2002; Zeghichi et al., 2003). Food and medical industries have shown increasing interest to Jute leaves because of the nutritional value (Oyedele et al., 2006; Dewanjee et al., 2013). In Bangladesh, jute leaves are available at cheap rate to offer popular vegetable dish. Although jute leaf as fish dietary protein source is not yet well established in the literature, the study of Singh et al. (2016) has shown some potentiality in carp diets. Therefore, the present study was conducted to evaluate jute leaf powder as feed ingredient for juvenile mrigal by progressively replacing fishmeal in their diet.

\section{Materials and Methods}

\section{Experimental design}

The study was carried out for 60 days in the "BAU Aquaponics Oasis" at the Department of Aquaculture, Bangladesh Agricultural University,
Mymensingh. The experimental design comprised of nine well aerated fish holding tanks (each of $0.26 \mathrm{~m}^{2}$ ), labeled and placed in two rows following complete randomized block design for experimental congeniality. The tanks were prepared by cutting, washing, drying, setting with aerators, filling up with water and covered with net frame to prevent the fish jumping out or predatory animals attack. Mrigal fingerlings (average size: $9.38 \pm 0.13 \mathrm{~cm}$ and $7.94 \pm 0.26 \mathrm{~g}$ ) were stocked at a density of 10 fingerlings/ 0.26 $\mathrm{m}^{2}$ tank after proper acclimatization.

\section{Collection and preparation jute leaf powder}

The jute leaves were collected from local market. After collection, the leaves were separated from stems, washed with tap water, aerated with electric fan in room condition to evaporate residual moisture and then dried in a homemade dryer at $40^{\circ} \mathrm{C}$. When jute leaves became crunchy they were finely ground using blender and then sieved. However, prior to formulating feed, prepared jute leaf powder was analyzed for nutritional profile (Table 1).

\section{Ingredients selection and fish feed formulation}

The following ingredients were selected for feed formulation based on their availability, nutrients content and market price (Table 2).

Table 1. Proximate composition of collected jute (Corchorus olitorius) leaf powder on wet matter basis (\%).

\begin{tabular}{|l|c|}
\hline \multicolumn{1}{|c|}{ Nutrients } & Composition (\%) \\
\hline 1. Moisture & $10.06 \pm 0.84$ \\
\hline 2. Crude lipid & $1.53 \pm 0.43$ \\
\hline 3. Crude protein & $28.83 \pm 1.25$ \\
\hline 4. Crude fiber & $7.36 \pm 0.74$ \\
\hline 5. Ash & $12.01 \pm 0.95$ \\
\hline 6. NFE (Nitrogen Free Extract) & $40.21 \pm 2.29$ \\
\hline
\end{tabular}

Table 2. The price of ingredients used in feed formulation for mrigal fingerlings.

\begin{tabular}{|l|c|}
\hline \multicolumn{1}{|c|}{ Name of ingredients } & Price $\left.(\mathrm{BDT} \mathrm{Kg})^{-1}\right)$ \\
\hline 1. Fish meal & 80 \\
\hline 2. Jute leaf powder & 30 \\
\hline 3. Mustard oil cake & 35 \\
\hline 4. Rice bran & 35 \\
\hline 5. Soya bean meal & 42 \\
\hline 6. Wheat flour & 25 \\
\hline 7. Soya bean oil and & 80 \\
\hline 8. Minerals and vitamin premix. & 100 \\
\hline
\end{tabular}

Feeds (test diets) were formulated by emphasizing progressive replacement of fishmeal with jute leaf powder. Three different test diets were formulated by replacing 0,10 and $20 \%$ of fish meal with jute leaf powder, which were designated as $\mathrm{T}_{0}, \mathrm{~T}_{10}$ and $\mathrm{T}_{20}$, respectively. In the control $\left(\mathrm{T}_{\mathrm{o}}\right)$, dietary inclusion of fishmeal was
30\% (but no jute leaf powder), which was substituted with jute leaf powder and subsequently reduced to $27 \%$ and $24 \%$ in $\mathrm{T}_{10}$ and $\mathrm{T}_{20}$, respectively. Inclusion rates of different feed ingredients were determined following Pearson's technique to prepare isonitrogenous (around $30 \%$ protein) test diets (Table 3 ). 
Table 3. Dietary inclusion rate (g) of different ingredients used in formulating $100 \mathrm{~g}$ of the test diets for mrigal fingerlings.

\begin{tabular}{|l|c|c|c|}
\hline Feed ingredients & $\begin{array}{c}\mathrm{T}_{0} \\
\text { (0\% replacement of } \\
\text { fish meal with jute leaf } \\
\text { powder) }\end{array}$ & $\begin{array}{c}\mathrm{T}_{10} \\
\text { (10\% replacement of } \\
\text { fish meal with jute leaf } \\
\text { powder) }\end{array}$ & $\begin{array}{c}\mathrm{T}_{20} \\
\text { (20\% replacement of } \\
\text { fish meal with jute leaf } \\
\text { powder) }\end{array}$ \\
\hline Jute leaf & 0 & 3 & 6 \\
\hline Fish meal & 30 & 27 & 24 \\
\hline Mustard oilcake & 15 & 13 & 13 \\
\hline Rice bran & 25 & 25 & 25 \\
\hline Soya bean & 10 & 15 & 21 \\
\hline Wheat flour & 15 & 12 & 3 \\
\hline Soya oil & 3 & 3 & 2 \\
\hline $\begin{array}{l}\text { Vitamin mineral } \\
\text { premix }\end{array}$ & 2 & 2 & 100 \\
\hline Grand Total & 100 & 100 & 3 \\
\hline
\end{tabular}

Sinking dry pellet feed $(1.5 \mathrm{~mm}$ diameter) was prepared with extruded feed pellet machine and sun dried. Prepared test diets were stored in air tight polythene bags at $4^{\circ} \mathrm{C}$ in refrigerator before feeding the fish. The proximate composition of the prepared test diets was also determined that has been shown in Table 4 (AOAC, 1990). Some precautionary measures were also taken in preparing the ingredients for feed formulation such as measured mustard oil cake was soaked overnight and soybean meal was pre-boiled to minimize their glucocyanate effects.

Table 4. Proximate composition (\%) of different test diets.

\begin{tabular}{|l|c|c|c|c|c|c|}
\hline Treatments & Moisture & Crude lipid & $\begin{array}{c}\text { Crude } \\
\text { protein }\end{array}$ & Ash & $\begin{array}{c}\text { Crude } \\
\text { fiber }\end{array}$ & NFE \\
\hline $\mathrm{T}_{0}$ & 12.88 & 5.65 & 30 & 12.54 & 4.34 & 33.49 \\
\hline $\mathrm{T}_{10}$ & 12.83 & 6.54 & 29.95 & 11.83 & 5.14 & 33.61 \\
\hline $\mathrm{T}_{20}$ & 13.68 & 5.45 & 30.01 & 11.60 & 5.79 & 33.27 \\
\hline
\end{tabular}

\section{Feeding of fish, sampling and data Low pH stress test}

\section{analysis}

The mrigal fingerlings were fed with the experimental diets at the rate of $10 \%$ of their body weight twice daily. The uneaten feed and faces were removed from the tanks with $25 \%$ daily water exchange through siphoning and the entire water changed fortnightly. Moreover, fish were sampled fortnightly throughout the study period in order to observe their growth response to the test diets by calculating the growth parameters such as length gain $(\mathrm{cm})$, weight gain (g), percent weight gain, specific growth rate (SGR, \% day-1), food conversion ratio (FCR), survival rate (\%) and fish production $\left(\mathrm{kg} \mathrm{ha}^{-1}\right)$. Fish carcass profile was also determined following the standard procedure of AOAC (1990). Besides, water quality parameters such as dissolved oxygen $\left(\mathrm{mg} \mathrm{L}^{-1}\right)$, water temperature $\left({ }^{\circ} \mathrm{C}\right), \mathrm{pH}$, ammonia and nitrite contents were measured using portable DO meter, thermometer, $\mathrm{pH}$ meter and ammonia testing kits, respectively. However, collected data were subjected to one-way ANOVA for statistical analysis (Snedecor and Cochran, 1994). The least significant difference was used for comparison of the mean values ascertained from different treatments.
Tolerance of the test fish against low $\mathrm{pH}$ stressor (pH 3) was also observed to determine the effect (if any) of the test diets on fish fitness. Therefore, after the feeding trial, two fish from each rearing tank (6 fish per treatment) were randomly selected and transferred to a $20 \mathrm{~L}$ bucket containing water having $\mathrm{pH} 3$. Deep tube-well water was strongly aerated for $24 \mathrm{~h}$ and gradually mixed with nitric acid $\left(\mathrm{HNO}_{3}\right)$ to avail this low $\mathrm{pH}$ water $(\mathrm{pH} 3)$. The tanks for stress test were equipped with continuous aeration and kept under ambient temperature. The passing of time to reach $50 \%$ mortality was calculated as median lethal time $\left(\mathrm{LT}_{50}\right)$.

\section{Results and Discussion}

Throughout the experiment, the test diets were well accepted by the juvenile mrigal as there was almost no feed left over after twenty minutes of feed delivery. Therefore, inclusion of jute leaf as a substitute of fishmeal presumably did not hamper the palatability of the test diets. Singh et al. (2016) similarly experimented with jute leaf powder in the diet of rohu (Labeo rohita) fingerlings and reported its suitability in carp diet. Regarding the survival rate, juveniles treated with jute leaf based diets in $T_{10}$ and $T_{20}$ 
experienced better survivals $(93.33 \%$ and $90.00 \%$, respectively) that were significantly superior $(\mathrm{P}<0.05)$ to those in $\mathrm{T}_{\mathrm{o}}$ with survival rate of $83.33 \%$. The higher survival rates in $\mathrm{T}_{10}$ and $\mathrm{T}_{20}$ might be attributed to the rich nutritional profile of jute leaves containing appreciable amount of minerals (viz. potassium, magnesium, iron, copper, and manganese) and vitamins (viz. $\mathrm{A}, \mathrm{C}, \mathrm{E})$ as well as lipid, protein, and carbohydrates (Steyn et al., 2001; Dansi et al., 2008).

The observed mean length gain and weight gain of mrigal fingerlings in the treatments were as follows: $\mathrm{T}_{\mathrm{o}}: 1.0 \pm 0.57 \mathrm{~cm}$ and $2.61 \pm 0.06 \mathrm{~g}, \mathrm{~T}_{10}$ : $1.51 \pm 0.18 \mathrm{~cm}$ and $2.96 \pm 0.13 \mathrm{~g}$ and $\mathrm{T}_{20}: 1.35 \pm 0.27$ $\mathrm{cm}$ and $2.52 \pm 0.57 \mathrm{~g}$, respectively (Table 5). Although both the parameters were statistically non-significant $(\mathrm{P}>0.05)$ among the treatments but $\mathrm{T}_{10}$ gave comparatively better fish increment.
Correspondingly, the highest SGR (\% day ${ }^{-1}$ ) and fish production $\left(\mathrm{kg} \mathrm{ha}^{-1}\right)$ were experienced in $\mathrm{T}_{10}$ $\left(0.53 \pm 0.03 \%\right.$ day $^{-1}$ and $\left.4084.0 \pm 50.67 \mathrm{~kg} \mathrm{ha}^{-1}\right)$ compared to $\mathrm{T}_{20} \quad\left(0.45 \pm 0.11 \%\right.$ day $^{-1}$ and $\left.4030.1 \pm 42.42 \mathrm{~kg} \mathrm{ha}^{-1}\right)$ and $\mathrm{T}_{0}\left(0.47 \pm 0.05 \%\right.$ day $^{-1}$ and $3979.8 \pm 45.04 \mathrm{~kg} \mathrm{ha}^{-1}$ ). However, the FCR (Food Conversion Ratio) was the lowest in $\mathrm{T}_{10}$ $(2.81 \pm 0.71)$ followed by $\mathrm{T}_{0}(3.19 \pm 0.16)$ and $\mathrm{T}_{20}$ $(3.30 \pm 3.15)$.

Giving insight to the growth performance of mrigal juveniles, all the parameters were statistically similar except the survival rate where jute leaf presumably performed the key role. Therefore, the results suggest that replacement of fishmeal with jute leaf in mrigal diet could be feasible, without hampering fish growth, which is in agreement with the results of Singh et al. (2016).

Table 5. Overall growth performance of mrigal fingerlings fed test diets.

\begin{tabular}{|c|c|c|c|c|c|c|}
\hline Parameters & $\begin{array}{c}\mathrm{T}_{0} \\
(\mathrm{o} \% \\
\text { replacement } \\
\text { of fish meal } \\
\text { with jute leaf } \\
\text { powder })\end{array}$ & $\begin{array}{c}\mathrm{T}_{10} \\
(10 \% \\
\text { replacement } \\
\text { of fish meal } \\
\text { with jute leaf } \\
\text { powder })\end{array}$ & $\begin{array}{c}\mathrm{T}_{20} \\
(20 \% \\
\text { replacement } \\
\text { of fish meal } \\
\text { with jute leaf } \\
\text { powder })\end{array}$ & $\begin{array}{c}\mathrm{F} \\
\text { value }\end{array}$ & $\begin{array}{c}\mathrm{P}- \\
\text { value }\end{array}$ & 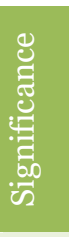 \\
\hline Mean initial length (cm) & $9.30( \pm 0.07)$ & $9.27( \pm 0.16)$ & $9.56( \pm 0.15)$ & 4.01 & 0.07 & NS \\
\hline Mean final length $(\mathrm{cm})$ & $10.30( \pm 0.61)$ & $10.78( \pm 0.06)$ & $10.91( \pm 0.11)$ & 2.34 & 0.17 & NS \\
\hline Mean length gain $(\mathrm{cm})$ & $1.00( \pm 0.57)$ & $1.51( \pm 0.18)$ & $1.35( \pm 0.27)$ & 0.47 & 0.64 & NS \\
\hline$\%$ length gain & $10.72( \pm 6.16)$ & $16.34( \pm 2.27)$ & $15.39( \pm 3.33)$ & 0.01 & 0.29 & NS \\
\hline Mean initial weight (g) & $7.88( \pm 0.05)$ & $7.81( \pm 0.20)$ & $8.11( \pm 0.52)$ & 0.68 & 0.54 & NS \\
\hline Mean final weight (g) & $10.50( \pm 0.11)$ & $10.78( \pm 0.13)$ & $10.63( \pm 0.11)$ & 3.81 & 0.54 & NS \\
\hline Mean weight gain & $2.61( \pm 0.06)$ & $2.96( \pm 0.13)$ & $2.52( \pm 0.57)$ & 1.36 & 0.32 & NS \\
\hline$\%$ weight gain & $33.17( \pm 0.60)$ & $37.96( \pm 2.67)$ & $31.73( \pm 9.01)$ & 1.07 & 0.39 & NS \\
\hline FCR & $3.19( \pm 0.16)$ & $2.81( \pm 0.71)$ & $3.30( \pm 3.15)$ & 0.73 & 0.73 & NS \\
\hline SGR $\left(\%\right.$ day $\left.^{-1}\right)$ & $0.47( \pm 0.05)$ & $0.53( \pm 0.03)$ & $0.45( \pm 0.11)$ & 1.04 & 0.40 & NS \\
\hline $\begin{array}{l}\text { Fish production }\left(\mathrm{kg} \mathrm{ha}^{-1}\right. \\
\left.60 \text { days }^{-1}\right)\end{array}$ & $\begin{array}{l}3979.80 \\
( \pm 45.04)\end{array}$ & $\begin{array}{l}4084.00 \\
( \pm 50.67)\end{array}$ & $\begin{array}{l}4030.10 \\
( \pm 42.42)\end{array}$ & 3.81 & 0.08 & NS \\
\hline Survival rate (\%) & $83.33^{\mathrm{a}}$ & $93.33^{\mathrm{b}}$ & $90.00^{b}$ & 4.28 & 0.04 & * \\
\hline
\end{tabular}

Note: Values are mean \pm Standard deviation from triplicate group. Values in a row having similar letters (s) or without letters do not differ significantly whereas values bearing the dissimilar letter (s) differ significantly as per DMRT (Duncan's New Multiple Range Test). * Significant at $P \leq 0.05$; NS non-significant at $P>0.05$.

Besides growth performance, the tolerance of the experimental fish to low $\mathrm{pH}$ stressor was also assessed (after the final harvest) where they were exposed to water $\mathrm{pH}$ 3.0. Water $\mathrm{pH}$ is an important regulator of cultured fish and tolerance to adverse $\mathrm{pH}$ mostly depends on the fish wellbeing. The recommended $\mathrm{pH}$ range for fish culture is $6.8-9.0$ whereas, $\mathrm{pH} 4.0$ or below is considered as the acid death point where most fish would die (Swingle, 1967). In this experiment, fish in $\mathrm{T}_{\mathrm{o}}$ showed the least tolerance to low $\mathrm{pH}$ stressor $\left(\mathrm{LT}_{50}=8\right.$ minutes). In comparison, $50 \%$ of the fish of $\mathrm{T}_{10}$ died within 16 minutes and of $\mathrm{T}_{20}$ died within 17 minutes $\left(\mathrm{LT}_{50}=\right.$ 16 and 17 minutes, respectively) after low $\mathrm{pH}$ exposure (Fig. 1). Such result signifies the incorporation of jute leaf powder in fish diet to make them more resilient.

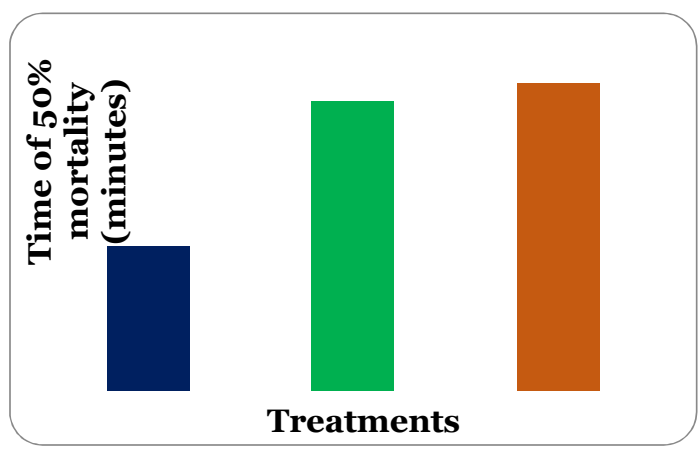

Fig. 1. Low pH stress test. 
Regarding the carcass compositions of the experimental juvenile mrigal, all the parameters (moisture, crude protein, crude lipid, crude fiber, ash and carbohydrate contents) were statistically similar $(\mathrm{P}>0.05)$ among the treatments (Table 6). Therefore, the results imply that the dietary replacement of fishmeal with jute leaf did not affect the nutrient profile of the fish. Although the observed carcass composition of mrigal juvenile were slightly higher than the findings of Singh et al. (2016), who applied jute leaf based diet in rohu (L. rohita) fingerlings. The possible reasons might be the presence of fishmeal in the test diets and different fish species subjected in the present experiment. However, further research with higher dietary inclusion of jute leaf in mrigal diets is necessary to visualize the amplified effect of jute leaf in the fish carcass profile. Notably, the incorporation of plant based diets has been reported to boost up carcass protein and fat levels in Indian major carps (Nandeesha et al., 1995).

Table 6. Proximate compositions of mrigal fingerlings (\% moisture basis) with different experimental diets.

\begin{tabular}{|c|c|c|c|c|c|c|}
\hline Parameters & $\begin{array}{c}\mathrm{T}_{0} \\
(\mathrm{o} \% \\
\text { replacement of } \\
\text { fish meal with } \\
\text { jute leaf } \\
\text { powder })\end{array}$ & $\begin{array}{c}\text { T10 } \\
(10 \% \\
\text { replacement of } \\
\text { fish meal with } \\
\text { jute leaf } \\
\text { powder })\end{array}$ & $\begin{array}{c}\mathrm{T}_{20} \\
(20 \% \\
\text { replacement of } \\
\text { fish meal with } \\
\text { jute leaf } \\
\text { powder })\end{array}$ & F value & $\mathrm{P}$-value & 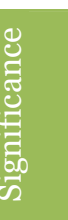 \\
\hline Moisture & $75.06( \pm 1.04)$ & $75.81( \pm 0.82)$ & $75.61( \pm 0.90)$ & 0.43 & 0.67 & NS \\
\hline Crude protein & $14.07( \pm 0.64)$ & $14.10( \pm 0.21)$ & $13.91( \pm 0.12)$ & 0.20 & 0.82 & NS \\
\hline Crude lipid & $4.93( \pm 0.41)$ & $5.13( \pm 0.32)$ & $4.49( \pm 0.16)$ & 3.25 & 0.11 & NS \\
\hline Crude fiber & $1.13( \pm 0.03)$ & $1.24( \pm 0.11)$ & $1.03( \pm 0.23)$ & 1.50 & 0.29 & NS \\
\hline Ash & $3.71( \pm 0.46)$ & $3.79( \pm 0.52)$ & $3.56( \pm 0.08)$ & 0.25 & 0.78 & NS \\
\hline Carbohydrate & $0.47( \pm 0.26)$ & $0.82( \pm 0.28)$ & $0.62( \pm 0.31)$ & 1.14 & 0.37 & NS \\
\hline
\end{tabular}

Note: Values are mean \pm Standard deviation from triplicate group. Values in a row having similar letters (s) or without letters do not differ significantly whereas values bearing the dissimilar letter (s) differ significantly as per DMRT (Duncan's New Multiple Range Test). * Significant at P $\leq$ 0.05; NS non-significant at P> 0.05.

Considering the feed cost, it was found that the expense of preparing the test diets increased with the inclusion level of fishmeal (Fig. 2). Correspondingly, the highest feed formulation cost was observed in $\mathrm{T}_{\mathrm{O}}\left(50.35 \mathrm{BDT} \mathrm{Kg}^{-1}\right)$ which was $3.7 \%$ higher than $\mathrm{T}_{10}\left(48.50 \mathrm{BDT} \mathrm{Kg}^{-1}\right)$ and 20.4\% higher than $\mathrm{T}_{20}$ (40.10 BDT $\left.\mathrm{Kg}^{-1}\right)$. Importantly, feed cost in aquaculture accounts for 70 to $75 \%$ of the total cost of fish production (Gadzama and Ndudim, 2019; Katheline et al., 2019). Therefore, substitution of fishmeal (animal protein) with jute leaf powder could considerably lessen the feed cost in aquaculture without affecting fish growth (Singh et al., 2018).

However, the water quality parameters viz. $\mathrm{pH}$, dissolved oxygen (DO), ammonia and nitrite contents in all the treatments (Table 7) were within the acceptable range for fish culture (Swingle, 1967; Rothius and Nhan, 1998; Paul et al., 2014). Therefore, suggesting that the experimental fish were not under stressed condition and water in the tanks did not play any decisive role in the feeding trials.

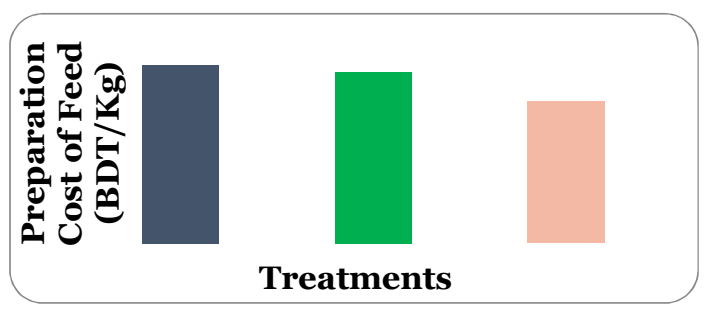

Fig. 2. Formulation cost of different test diets (BDT Kg-1).

Table 7. Water quality parameters of different treatments during the experimental period.

\begin{tabular}{|l|c|c|c|}
\hline \multicolumn{1}{|c|}{ Parameters } & $\begin{array}{c}\mathrm{T}_{0} \\
\text { (0\% replacement of fish } \\
\text { meal with jute leaf } \\
\text { powder) }\end{array}$ & $\begin{array}{c}\mathrm{T}_{10} \\
\text { (10\% replacement of } \\
\text { fish meal with jute leaf } \\
\text { powder) }\end{array}$ & $\begin{array}{c}\mathrm{T}_{20} \\
\text { (20\% replacement of } \\
\text { fish meal with jute leaf } \\
\text { powder) }\end{array}$ \\
\hline pH & $7.45( \pm 0.18)$ & $7.50( \pm 0.12)$ & $7.69( \pm 0.10)$ \\
\hline DO $\left(\mathrm{mg} \mathrm{L}^{-1}\right)$ & $5.56( \pm 0.31)$ & $5.05( \pm 0.64)$ & $5.90( \pm 0.10)$ \\
\hline Temperature $\left({ }^{\circ} \mathrm{C}\right)$ & $26.43( \pm 0.47)$ & $25.86( \pm 0.75)$ & $25.30( \pm 0.67)$ \\
\hline Ammonia $\left(\mathrm{mg} \mathrm{L}^{-1}\right)$ & $0.08 \pm 0.02$ & $0.07 \pm 0.02$ & $0.07 \pm 0.01$ \\
\hline Nitrite $\left.\left(\mathrm{mg} \mathrm{L}^{-1}\right)\right)$ & $0.62 \pm 0.07$ & $0.57 \pm 0.04$ & $0.61 \pm 0.04$ \\
\hline
\end{tabular}

\section{Conclusion}

Reducing feed cost has always been a crucial issue in aquaculture. The current venture promotes the dietary inclusion of jute leaf powder in order to cost effectively replace fish meal in the diets of mrigal fingerlings without adversely affecting fish growth and carcass composition at improved survival. 


\section{References}

Alceste, C. 200o. Tilapia: alternative protein sources in tilapia feed formulation. Aquacult. Maga. 26: 4.

Al-Mamun, M., Saha, C.K., Mostofa, M.G., Miah, A. and Hossain, M.Z. 2017. Identification of suitable varieties for seed production of jute in non-traditional areas of Bangladesh. Bangladesh J. Plant Breed. Genet. 30(1): 33-37. https://doi.org/10.3329/bjpbg.v30i1.36531

AOAC. 1990. Official methods of analysis. $15^{\text {th }}$ edn. Association of Official Analytical Chemists, Washington, D.C., USA. 318p.

Dansi, A., Adjatin, A., Adoukonou-Sagbadja, H., Faladé, V., Yedomonhan, H., Odou, D. and Dossou, B. 2008. Traditional leafy vegetable and their use in the Benin Republic. Genet. Resour. Crop. Evol. 55: 1239-1256. https://doi.org/10.1007/s10722-008-9324-Z

Dewanjee, S., Gangopadhyay, M., Sahu, R. and Karmakar, S. 2013. Cadmium induced pathophysiology: prophylactic role of edible jute (Corchorus olitorius) leaves with special emphasis on oxidative stress and mitochondrial involvement. Food Chem. Toxicol. 60: 188-198. https://doi.org/10.1016/j.fct.2013.07.043

FAO. 2012. Fisheries Statistics. Food and Agricultural Organization of the United Nations (FAO), Rome, Italy. 230p.

FAO. 2018. The State of World Fisheries and Aquaculture, Contributing to food security and nutrition for all. Food and Agricultural Organization of United Nations (FAO), Rome, Italy. 227p.

Francis, G., Makkar, H.P. and Becker, K. 2012. Products from little researched plants as aquaculture feed ingredients. The State of Food and Agriculture 2003-04, Food and Agriculture Organization of the United Nations. Food \& Agriculture Org. p.209. Agrippa-FAO online Journal (www. fao.org/Agrippa).

Furumuto, T., Wang, R., Okazaki, K., Hasan, F.A.F.M. and Ali, I.M. 2002. Antitumour promoters in leaves of jute (Corchorus capsularis and Corchorus olitorius). Food Sci. Tech. Res. 8: 239-243. https://doi.org/10.3136/fstr.8.239

Gadzama and Ndudim. 2019. Nutritional composition of housefly larvae meal: a sustainable protein source for animal production - a review. Acta. Sci. Agric. 3(4): 74-77.

Hardy, R.W. 1999. Aquaculture's rapid growth requirements for alternate protein sources. Feed Manage. 50: 25-28.

Katheline, H., Jennifer, M.C., Andrew, C., Kelly, C., Dean, R.J., Arnold, M., Christina, P., Matthew, J.V., Chaoshu, Z., Kyall, Z., Jan, M.S. 2019. The future of aquatic protein: Implications for protein sources in aquaculture diets. One Earth 1(3): 316-329. https://doi.org/10.1016/j.oneear.2019.10.018

Magouz, F.I., El-Gendi, M.O., Salem, M.F.I. and Elazab, A.A. 2008. Use of cucumber, squash and broad bean leaves as non-conventional plant protein sources in Nile tilapia (Oreochromis niloticus) diet. pp. 847-859. In: $8^{\text {th }}$ International Symposium on Tilapia in Aquaculture. The Central Laboratory for Aquaculture Research, October 12-14, 2008, Cairo, Egypt.

Munguti, J.M., Liti, D.M., Waidbacher, H., Straif, M. and Zollitsch, W. 2006. Proximate composition of selected potential feedstuffs for Nile tilapia (Oreochromis niloticus Linnaeus) production in Kenya. Di. Bodenkult. 57(3): 131-140.

Nandeesha, M.C., De Silva, S.S. and Krishna, D. 1995. Use of mixed feeding schedules in fish culture: performance of common carp, Cyprinus carpio L. on plant and animal based diets. Aquacult. Res. 26: 161-166. https://doi.org/10.1111/j.1365-2109.1995.tboo898.x

Oyedele, D.J., Asonugho, C. and Awotoye, O.O. 2006. Heavy metals in soil and accumulation by edible vegetables after phosphate fertilizer application. J. Agric. Food Chem. 5: 1446-145.3.

Paul, B.N., Pandey, B.K. and Giri, S.S. 2014. Effect of plant based feed attractants on growth of Cirrhinus mriqala fingerlings. Anim. Nutr. Feed Tech. 14(2): 393-398. $\quad$ https://doi.org/10.5958/0974181X.2014.01338.9

Rothius, A.J. and Nhan, D.K. 1998. Rice with fish culture in the semi-deep waters of the Mekong Delta, Vietnam: a socio-economical survey. Aquacult. Res. 29: 47-57. https://doi.org/10.1111/j.1365-2109.1998.tbo1099.x

Saha, C.K. 2011. Jute seed management in Bangladesh. pp. 305-310. In: Proceedings, International Seminar on Strengthening of Collaboration for Jute, Kenaf and Allied Fibres Research and Development, 8-9 June, 2011. International Jute Study Group (IJSG), Dhaka, Bangladesh.

Singh, P., Paul, B.N. and Giri, S.S. 2018. Potentiality of new feed ingredients for aquaculture: A review. Agril. Rev. 39: 282291. https://doi.org/10.18805/ag.R-1819

Singh, P., Paul, B.N., Rana, G.C. and Giri, S.S. 2016. Evaluation of jute leaf as feed ingredient for Labeo rohita fingerlings. Indian J. Anim. Nutr. 33(2): 203-207. https://doi.org/10.5958/2231-6744.2016.00034.7

Snedecor, G.W. and Cochran, W.G. 1994 Statistical methods. Oxford and IBH Publishing Company, Calcutta, West Bengal, India. p. 64.

Steyn, N.P., Olivier, J., Winter, P., Burger, S. and Nesamvuni, S. 2001. A survey of wild, green, leafy vegetables and their potential in combating micronutrient deficiencies in rural populations. South African J. Sci. 97: 276-279.

Swingle, H.S. 1967. Standardizations of chemical analyses for water and pond muds. FAO Fish Rep. 4: 397-421.

Tacon, A.G.J. and Metian, M. 2008. Global overview on the use of fish meal and fish oil in industrially compounded aquafeed: trends and future prospects. Aquac. 285: 148-158. https://doi.org/10.1016/j.aquaculture.2008.08.015

Zeghichi, S., Kallithraka, S. and Simopoulos, A.P. 2003. Nutritional composition of molokhia (Corchorus olitorius) and stamnagathji (Cichorium spinosum). World Rev. Nutr. Diet. 91: 1-21. https://doi.org/10.1159/0ooo69924 